\title{
Reconstruction of Criminal Sanction and Rehabilitation Combating On Narcotic's Victims Based On Religious Justice
}

\author{
Carto Nuryanto ${ }^{1}$
}

\begin{abstract}
During this time, law enforcement officials tend to impose criminal sanctions for victims of drug without rehabilitation but instead provide criminal sanctions such as prison. Without the detoxification process through medical and social rehabilitation process, they will soon be back looking for narcotics so out of prisons because of the association in the increasingly severe prison ${ }^{2}$, As described in Act No. 35 of 2009 on Narcotics Article 54 that the rehabilitation of abusers of Narcotics; "Addicts Narcotics and Narcotics abuse on victims to undergo mandatory medical rehabilitation and social rehabilitation". It is strengthened by the Supreme Court Circular No. 04 of 2010 concerning the Placement, Victims and Narcotic Addict Into The Rehabilitation Institute of Medical and Social Rehabilitation. Because of their position in this case is the victim, not the dealer let alone active users is appropriate that they get special treatment before the law. Law enforcement officials are supposed to be representatives of God on earth to be a judge and establishing the truth, fairest, it erred in sentencing. Besides religiously also does not reflect the nature of God's servants who are wise and fair.
\end{abstract}

Keywords: Reconstruction; Sanctions; Narcotic's Victim; Religious Justice.

\section{Introduction}

Narcotic's victims in Indonesia continues to increase, with the average growth rate of 0.03 percent. Narcotics number of users currently reaches over 5.2 million people. Even so the growth rate is still below the national threshold limit set BNN and the Ministry of Health by 0.05 percent $^{3}$. Victims of abuse of narcotics and drugs - illicit drugs (narcotics) in Central Java in 2017 reached more than 523 thousand people 4 . Meanwhile, data from the Central Statistics Agency of Central Java in 2018 the number of people in there were 34,257,865 inhabitants. If the calculation of the amount, then addicts Narcotics in Central Java there are as many as 397391 inhabitants ${ }^{5}$. So that drug crime is an Extraordinary Crime. And because the circulation is so large network of cross-border narcotics crime is also called Transnational Crimes ${ }^{6}$.

\footnotetext{
${ }^{1}$ Indonesian Police and Student's Doctor of Law, Sultan Agung Islamic University in Semarang, email: cartonurnyanto@gmail.com

2S. Wiljatmo. 1979. Pengantar Ilmu Hukum. Yogyakarta: Lukman Opset. p 20.

3 Tempo,' 200 Million People Annually Dies because Drugs', http://www.tempo.co/read/news/2014/06/26/173588287/200-Juta-Orang-Meninggal-AkibatNarkoba-per -year, accessed on October 2, 2018. ${ }^{4}$ http://www.krjogja.com/web/news/read/52042/Di_Jateng_Pengguna_Narkoba 523 Ribu_Orang, accessed on October 2, 2018.

5https://www.suaramerdeka.com/news/baca/129830/pengguna-narkoba-capai-35-juta-orang, accessed on October 2, 2018.

${ }^{6}$ S. Wiljatmo, Op.Cit. p 20.
} 
In Act 35 of 2009 on Narcotics actually have a soul or spirit to save abusers of narcotics ${ }^{7}$, Especially implicit in Article 4 of Act No. 35 of 2009 letter b stated clearly that this law aims to prevent, protect, and save the people of Indonesia on the abuse of narcotics. While the letter $d$ mentioned that this law guarantees the setting of medical and social rehabilitation efforts for abusers and addicts Narcotics ${ }^{8}$.

This Act also mandates law enforcement, especially investigators and prosecutors to protect, save and guarantee the drug abusers who are not in the category of active users (victims, whether coercion or other eksteral factor) to be rehabilitated. However, more than 90\% defendant drug abusers who do not comply with Article 112 received the investigator suspicion as criminals rather than the victims and obtain alternative charges or subsidiary charge or cumulative charge in the judicial process so that they are put in prison without the rehabilitation process. It is the basic need for a reconstruction of God's law so that justice can be achieved at least ${ }^{9}$.

\section{Research Methods}

This type of research is a qualitative research with Socio-Legal approach. That is reviewing normative legal from the standpoint of sociology as an interpretation or Interpretation Understanding. Socio-Legal approach tries to see the problems not only from the law perspective but also understanding the mental and see heart by heart of the victim in this research is Narcotic's victims so the judges or the law enforcement actors will not wrong in the Sanction. And while collecting data with literature study and interview.

\section{Results And Discussion}

\subsection{Narcotics}

Narcotic's problem is a big problem that is faced by the countries in the world, including ASEAN countries, such as Indonesia, Malaysia, Singapore, Vietnam and Thailand. ${ }^{10}$ In Indonesia, according to the National Narcotics Agency (BNN) No. SE / 03 / IV / 2002 / BNN, acronym of drugs are narcotics, psychotropic and addictive substances which, when entered into the human body affects the brain / central nervous system that lead to physical health problems, changes in behavior,

\footnotetext{
${ }^{7}$ O.C. Kaligis \& Associates. 2002. Narkoba dan Peradilannya di Indonesia, Reformasi Hukum Pidana Melalui Perundangan dan Peradilan. Bandung: Alumni. p. 260.

8 Ibid.

${ }^{9}$ Samosir, Djisman. 1992. Fungsi Pidana Penjara Dalam Sistem Pemidanaan di Indonesia. Bina Cipta. Bandung, p. 67

10 Upaya ASEAN Dalam Mencapai ASEAN Drugs Free 2015", dalam http://dedihumas.bnn.go.id/read/section/artikel/2013/01/08/544/upaya-asean-dalammencapai-drug-free-asean-2015
} 
feelings and thoughts ${ }^{11}$.

In Article 1 point 12 of the Law on Narcotics, explained that addicts are people using or abusing drugs and in a state of dependency on drugs, both physically and psychologically. And drug abuse as the following factors: 1) Internal Factors $^{12}$; Selfish feeling, Will Want Free, Jolt Life, Desire to know. ${ }^{13}$ 2) External Factors $^{14}$; Economic circumstances, the Community Environment, Environmental School/Work ${ }^{15}$, Convenience, Less supervision, Law factor. ${ }^{16}$

\subsection{Narcotics Sanction in Indonesia}

Currently, Indonesia has Act No. 35 of 2009 on Narcotics (State Gazette of 2009 No. 143), dated October 12, 2009, which replaced Act No. 22 of 2007 on Narcotics (State Gazette of 2007 Number 67).

Proof of narcotics abuse on victims as stipulated in Act No. 35 of 2009 on Narcotics, is difficult, because they have to look at the beginning of drug users using drugs and required proof that drug users when using the drug in a condition coaxed, tricked, deceived, forced and / or threatened to use narcotics. In the implementation of the Supreme Court issued a breakthrough by issuing Circular (SEMA) No. 04 of 2010, which became grip consideration of the judge in deciding narcotics.

Therefore, the drug addict as well as victims worthy to rehabilitation. However, due to drug addicts as well as a criminal / crime then he must still be punished with a sentence commensurate, because of this reason, it is said that the Double-Track System in the formulation of sanctions against the crime of drug abuse is the most appropriate. ${ }^{17}$

\subsection{Reconstruction of Criminal Sanction Policies and Actions In Law Enforcement Combating Narcotics Victims Delivering in Religious Justice}

On Tuesday, May 14, 2019, researchers conducted a study in Semarang Prison Class I or better known as LP Kedungpane located on Jl. Raya SemarangKm.4 Boja Semarang. Researchers interviewed the Head of Section Guidance Society (Kasi Binmas), Mrs. Ari Tris Ochtia Sari who also serves as a psychologist there said that the number of inmates narcotics were in LP Kedungpane most are

\footnotetext{
${ }^{11}$ (BNN) No. SE / 03 / IV / 2002 / BNN

${ }^{12}$ A.W. Widijaya. 1985. Masalah Kenakalan Remaja dan Penyalahgunaan Narkotika.Penerbit Armico. Bandung. p. 25

13 Ibid.

${ }^{14}$ Ibid, p. 30

${ }^{15}$ Hari Sasangka. 2003. Narkotika dan Psikologi Dalam Hukum Pidana Untuk Mahasiswa dan Praktisi serta penyuluh Masalah Narkotika. Bandung. Cet I. Penerbit Mandar Maju, p. 6

${ }^{16}$ Ar.Sujono dan Bony Daniel. 2011. Komertar dan pembahasan Undang-Undang Nomor 35 Tahun 2009 Tentang Narkotika. Cet ke 1. Penerbit sinar Grafika, p.224

17 Dwi Wihamhyarti, Implementasi Sanksi Pidana dan Sanksi Tindakan dalam Kebijakan Hukum Pidana di Indonesia, Semarang, 2011.
} 
those who at the time were caught were found weight of the item (B) of less than 1 g. He also wondered why BB less than 1 gram was directed to criminal sanctions (imprisonment) is not sanctioned rehabilitation. He revealed that many inmates who are disappointed with the verdict in the trial that led to their hard-nurtured for at LP for reasons of dissatisfaction and disappointment ${ }^{18}$.

More mencengankan again when we interviewed the two (2) inmates ie mr. Rico Tambunan (Age 49) were sentenced to prison for 1 year with a weight of 0.2 grams evidence from the date of 8 September 2018 by police Genuk. While mr. Wahyu Adi (Age 40) was sentenced to 1.3 years with a weight of 0.37 grams evidence. Two of the prisoners said that the two had never sanction and rehabilitation for at LP Kedungpane, only socialization alone the dangers of drugs and how to re-blend to the public ${ }^{19}$.

From here we can analysis that most of the inmates were sentenced to criminal sanctions is a user group (victims) are not dealers but they were imprisoned on the grounds had abused narcotics attributed by investigators to Article 127 Act No. 35 of 2009 on Narcotics neighbor.

Decriminalization of drug abusers is indeed difficult to understand by people and law enforcement for not socialized properly and not taught in law school in Indonesia. This is because it is taught only criminal justice system. As a result, when the Act No. 35 of 2009 which embraces justice system rehabilitation with decriminalize narcotics case, then a lot of people and law enforcement officers who stutter because of his mindset still criminal justice system ${ }^{20}$.

Based on the above discussion Reconstruction Of Criminal Sanction Policies And Actions In Law Enforcement Combating Narcotics Victims Delivering In Religious Justice is as follows ${ }^{21}$ :

1) To accelerate the revision of Act No. 35 of 2009 on narcotics which have been included in the list of the national legislation to accommodate various improvements shortage Narcotics Law mainly handling Narcotics victims;

2) Prevention narcotics new kinds and types of precursors of narcotic new (new psychoactive substances) through the legal norms more comprehensive form of an annual evaluation and renewal of the legislation related to the type of drug, as well as the prosecution is expressly industrial non-pharmaceutical categorized deviating production of precursors of narcotic new;

3) The preparation of sustainable development programs for the golden generation of Indonesian drug free through a special curriculum design of a

\footnotetext{
18 Interview with Head of the Community Guidance Section (Kasi Binmas), Mrs. Ari Tris Ochtia Sari in Semarang Prison Class I, on May 14, 2019, at: 13:30 am

${ }^{19}$ Interviews with two inmates narcotics, mr. Rico Tambunan and mr. Wahyu Adi in Semarang Prison Class I, on May 14, 2019, at: 14:00 pm

20 Ibid.

${ }^{21}$ BNN, Ministry of Health and Social Affairs, analysis, Source Timahli Commission III DPDRI
} 
drug abuse prevention learners basic level, intermediate, and universities need to strengthen coordination with the inherent BNN to conduct surveillance on a regular basis;

4) Rehabilitation programs through (a) an increase in the infrastructure budget allocated rehabilitation centers, both in the State Budget and Budgets; (B) the adoption of a religious approach in drug rehabilitation center owned by the government; and (c) the establishment of interagency coordination forum that did rehabilitation for drug abusers.

\section{Closing}

\subsection{Conclusion}

In some ways it can be said that the law enforcement policy in narcotic crime decline. See note resolving cases ever handled and based on the development of drug-related legal policy in general is in the study of the United Nations, Indonesia is still in the state with legal policies that have not still need to be repaired, or in other words the need for reconstruction. Especially weaknesses in law enforcement is situated on the aspect of anticipation and post narcotics abuse. The role of the apparatus is still a key highlight in the value decline in the quality of law enforcement. It is also the result of weaknesses in the law (Act) that has been set by the government.

\subsection{Suggestion}

The suggestion in this research is divided in three majors, they are: 1) For the government should be focus to the policies and the law/act which given to the all people so the ultimate goal of the justice will be appear. 2) For the judge should be understanding not only the legal aspects but also the sociological aspects so if give the sanction to the narcotic's victim will be fair and still understood the humanity aspects for the justice through the sanctions and rehabilitations. 3) For the narcotic's victim should understand what's the effect of the narcotic abuse in the life and the policies.

\section{Bibliography}

[1] (BNN) No. SE/03/IV/2002/BNN

[2] A.W. Widijaya. 1985. Masalah Kenakalan Remaja dan Penyalahgunaan Narkotika.Penerbit Armico. Bandung.

[3] Ar.Sujono dan Bony Daniel. 2011. Komertar dan pembahasan Undang-Undang Nomor 35 Tahun 2009 Tentang Narkotika. Cet ke 1. Penerbit sinar Grafika.

[4] BNN, Kemenkes, dan Kemensos, analisa, Sumber Timahli Komisi III DPDRI

[5] Dwi Wihamhyarti, Implementasi Sanksi Pidana dan Sanksi Tindakan dalam Kebijakan Hukum Pidana di Indonesia, Semarang, 2011. 
[6] Hari Sasangka. 2003. Narkotika dan Psikologi Dalam Hukum Pidana Untuk Mahasiswa dan Praktisi serta penyuluh Masalah Narkotika. Bandung. Cet I. Penerbit Mandar Maju.

[7] O.C. Kaligis \& Associates. 2002. Narkoba dan Peradilannya di Indonesia, Reformasi Hukum Pidana Melalui Perundangan dan Peradilan. Bandung: Alumni.

[8] S. Wiljatmo. 1979. Pengantar Ilmu Hukum. Yogyakarta: Lukman Opset.

[9] Samosir, Djisman. 1992. Fungsi Pidana Penjara Dalam Sistem Pemidanaan di Indonesia. Bina Cipta. Bandung.

\section{Legislation:}

[1] Constitution of the Republic of Indonesia of 1945

[2] Book of the Criminal Justice Act

[3] Act No. 8 of 1981 on the Law of Criminal Procedure

[4] Act No. 12 of 1995 regarding Correctional

[5] Act No. 35 of 2009 on Narcotics

[6] Government Regulation No. 31of 1999 on Coaching and Mentoring Citizens Patronage of Corrections

[7] Supreme Court Circular No. 04 of 2010 regarding the determination of abuse, victims of abuse, and the Narcotic Addict Rehabilitation Institute in Medical and Social Rehabilitation

\section{Internet:}

[1] http://www.krjogja.com/web/news/read/52042/Di_Jateng_Pengguna_Narko ba_523_Ribu_Orang

[2] https://www.suaramerdeka.com/news/baca/129830/pengguna-narkobacapai-35-juta-orang

[3] Tempo, "200 Million People Annually Dies Because Drugs", http://www.tempo.co/read/news/2014/06/26/173588287/200-Juta-OrangMeninggal-Akibat-Narkoba-per -year, accessed on October 2, 2018.

[4] ASEAN's efforts in Achieving Drug Free ASEAN 2015, in http://dedihumas.bnn.go.id/read/section/artikel/2013/01/08/544/upayaasean-dalam-mencapai-drug-free- asean-2015

\section{Interview:}

[1] Interview with Head of the Community Guidance Section (Kasi Binmas), Mrs. Ari Tris Ochtia Sari in Semarang Prison Class I, on May 14, 2019, at: 13:30 am

[2] Interviews with two inmates narcotics, Bp. Rico Tambunan and Bp. Wahyu Adi in Semarang Prison Class I, on May 14, 2019, at: 14:00 pm 
Reconstruction of Criminal Sanction...

(Carto Nuryanto) 